\title{
From the theater to the hippodrome: A critique of Jeffrey Green's theory of plebiscitary democracy and an alternative
}

\author{
Gábor Illés ${ }^{\mathrm{a}}{ }_{(\mathbb{D}}{ }^{*}$ and András Körösényi ${ }^{\mathrm{b}}$ (D) \\ ${ }^{a}$ Centre for Social Sciences, Eötvös Loránd Research Network (ELKH), Budapest 1052, Hungary \\ illes.gabor@tk.hu. \\ ${ }^{\mathrm{b}}$ Faculty of Law, Eötvös Loránd University, Budapest 1053, Hungary \\ korosenyi.andras@tk.hu.
}

*Corresponding author.

\begin{abstract}
The article argues that the theory of plebiscitary leader democracy (PLD), originally developed by Max Weber, is in its somewhat rejuvenated version a helpful framework in interpreting longer-term and more recent empirical trends in contemporary democracies, such as the growing personalization of politics, the emergence of populist leaders, rising levels of polarization, and the growing importance of social media. However, to realize the potential of the theory, it should be detached from Jeffrey Green's most original, yet insufficiently realistic elaboration of plebiscitary democracy that he made a decade ago. The article argues that instead of a passive and unifiable entity, the citizenry should be thought of as reactive and deeply divided, a setting which can be characterized by the metaphor of the infamous Byzantine chariot races rather than that of the theater, implicit in Green's theory. Plebiscitary democracy should be thought of as representational, where popular control is manifested as the veto power of the popular voice. Additionally, despite its realist minimalism, the theory we propose may still have some critical potential, because it adopts the refurbished ideal of competition. The article closes by identifying further avenues of theoretization leading towards a more elaborate view of PLD.
\end{abstract}

Contemporary Political Theory (2022) 21, 419-442. https://doi.org/10.1057/s41296021-00525-6; advance online publication 6 October 2021

Keywords: plebiscitarianism; Max Weber; representation; competition; polarization; ocular model of democracy

'In a democracy the people choose a leader whom they trust. Then the chosen man says, "Now shut your mouths and obey me". The people and the parties are no longer free to interfere in the leader's business' - Max Weber reportedly said during a conversation in 1919. "I could like such a "democracy" - his 
conversation partner, General Erich Ludendorff answered (quoted in Radkau, 2009, p. 543). The quotation marks and the sympathy in Ludendorff's answer are telling: it is unlikely that this kind of democracy would appeal to most of us. But what about the descriptive accuracy of the Weberian view? And is it possible that Weber's more elaborated theory, that of plebiscitary leader democracy (PLD), may still have some normative merit? And most importantly: how is a hundred-year old description of the functioning of democracy relevant today?

The goal of the article is to answer these questions. By conjoining theorizing and empirical political science results, it aims at a realistic (i.e. empirically informed) political theory of plebiscitary democracy. ${ }^{1} \mathrm{We}$ argue that certain longer-existing and more recent trends, including the transformation of social cleavages, the diminishing role of parties and parliaments, the mediatization and growing personalization of politics, the emergence of populist leaders, and the new arenas and technologies of political communication (e.g. Dalton and Wattenberg, 2000; Mair, 2013; Moffitt, 2016; Karvonen, 2009; Poguntke and Webb, 2005; van Aelst et al., 2017) make the original Weberian idea of PLD helpful in understanding the functioning of contemporary democracies.

However, this is not exactly what Jeffrey Edward Green's most elaborate and most innovative contemporary theory of plebiscitary democracy (2010; cf. 2016) proposes. Therefore, the first part of our argument will be negative: after introducing Green's theory, we show that it is not realistic, which is made even more evident by recent trends. After making these critical remarks, our aim will be to elaborate starting points for a more realistic version of plebiscitarianism under contemporary conditions. This account will fill a void in contemporary democratic theory: despite the valuable discussions of how Weber's vision of parliamentarism (Palonen, 2018) and his notion of charismatic leadership (Kalpokas, 2019, p. 40; Iosifidis and Wheeler, 2018, pp. 4-8; Spoelstra, 2020) could be useful in interpreting contemporary trends, and an application of the framework of PLD to backsliding democracy (Körösényi et al., 2020), to our knowledge there is no systematic account of how the Weberian idea of plebiscitarianism is applicable to today's democratic politics.

The first part of the article situates the discussion by giving a preliminary account of what the Weberian PLD means. The second part follows with a short review of Green's interpretation of plebiscitarianism, at the same time showing how longer existing and more recent empirical trends problematize Green's claim that his theory is realistic. The third part elaborates on our initial account of PLD, showing how plebiscitarianism may be democratic, and what political values it may serve. Additionally, this part points towards possible further avenues of theoretization. 


\section{Plebiscitary Democracy: A Weberian Starting Point}

PLD is centered around the notion of charisma, in the original Weberian formulation: 'the personal quality that makes an individual seem extraordinary, a quality by virtue of which supernatural, superhuman, or at least exceptional powers or properties are attributed to the individual' (Weber, 2019, p. 374). Charisma is a relational category, denoting a connection between the charismatic person (e.g. prophet or political leader) and their followership; the exceptional qualities need to be constantly proved, and acknowledged by the followers. Weber treated PLD as an 'antiauthoritarian reinterpretation' or 'redefinition' (herrschaftsfremde Umdeutung) of charisma (Weber, 2019, pp. 405, 408; Weber, 1922, pp. 155-158), where the leaders' acceptance by the electorate is not the effect, but the cause of their legitimacy (unlike in the pure version of charisma). This means that a rational element of legitimation (e.g. in the form of regular elections) is blended with the charismatic one; Weber refers to this blend as 'democratic legitimacy' (Weber, 2019, p. 405).

Cast in more general terms, PLD is a personalized political setting ruled by the binary logic of yes or no: political leaders either gain acceptance or earn rejection, and there is ususally no place for further rational argument, deliberation, or the pondering of political manifestos or governmental records. While charismatic leaders' followership consists of the yea-sayers, there is always an opposing camp that rejects them (and may support another charismatic politician, if there is one). This logic pervades every institution, not just plebiscites, referenda, and consultations: elections, too, become de facto plebiscites about the charismatic leader's person. The notion of PLD is, therefore, broader than electoral or direct democracy, as it may integrate various institutions into its personalized and binary logic.

Finally, leaders who prevail in the political struggle and take office usually claim to represent the people (not only their followership, but also the nay-sayers), and ground their legitimacy on its acceptance. As Weber puts it: 'Wherever legitimacy for this kind of rule is sought, it makes use of plebiscitary recognition by the sovereign people [das souveräne Volk]' (Weber, 2019, p. 407; Weber, 1922, p. 156). But in the same place, he also makes it clear that such democratic legitimacy does not equal the rule of the people. It is rather leaders who rule, hiding this fact behind the 'will of the ruled' (Weber, 2019, p. 407; Wille der Beherrschten - Weber, 1922, p. 156). This means that the popular will grounding the leaders' legitimacy is not autonomous but is rather preformed by leadership: it is the latter that offers interpretive frames and sets the alternatives - the role of the narrower followership and the broader electorate in PLD is reactive and consists merely in accepting or rejecting these alternatives. The binary logic of the plebiscite (yes or no, acceptance or rejection without further questioning) is the best testimony of the 
limits of popular rule. This is the core of Weberian elitism and his account of leadership in democracies (Pakulski and Körösényi, 2012).

After a century, the Weberian description of PLD may gain further traction thanks to the transformation of cleavage politics, growing personalization, and recent technological changes. The latter includes new, digital plebiscitary techniques (e.g. social media rallies, and digital consultations - Hendriks, 2020) that may make the direct interaction between charismatic leaders and their followership easier. Moreover, one can think in broader terms, as the basic logic of following personalities and distributing 'likes' (and 'dislikes' on some platforms) in social media corresponds to the basic yes or no logic of PLD. In this sense, we live in a 'society of perpetual referendums' (Davies, 2020). These phenomena highlight that while elections and formal referenda remain central to PLD, the theory points well beyond the questions of electoral or direct democracy and involves broader spheres of our everyday political experience.

\section{Green's Plebiscitarianism and Its Problems}

Green's theory is a version of plebiscitary democracy, which innovatively reinterprets it at certain points. He presents a novel reading of the theorists of plebiscitarianism (Weber, Schumpeter, Schmitt, and others), which results in what Green calls the 'ocular model of popular empowerment' (Green, 2010, pp. 7-17), a counterpoint to the more traditional 'vocal model' adopted by participatory theories. Let us unpack Green's ocular model, and simultaneously show its three problematic points.

Primarily, it should be noted that Green sees his theory as post-representational, i.e. as a possible way out of the concept of representation. He justifies this move by pointing towards the problems of the concept, inter alia, that it relies on the old metaphysical picture of subject and object (an expressive people and a government that faithfully mirrors its preferences); that it is generally unverifiable (judging the correctness of representation is a matter of taste); and that the realizability of accountability is problematic, either because the appropriate popular inputs are lacking, or because of the flaws of the existing electoral machine (Green, 2010, pp. 17-19).

Green's ocular model is based on the insight that citizens usually relate to political events as spectators: echoing Weber's view, the model sees leaders as active agents of the political process, and - making a seemingly tiny move away from the Weberian description - the citizenry as passive, nonparticipatory recipients of political messages. (Green, 2010, p. 17).

In our view, this is the first problematic point of his theory: it does not consider the changes generated by the technological revolution in the media and in political communication - partly because most of these changes have happened since he 
published his book. Although Green captures the asymmetry between leaders and citizens well, disclosing the problems of the participatory view, the characterization of the citizenry as completely passive is problematic (cf. Abbey, 2014; Fitzgerald, 2015a, 2015b; Tønder, 2015), and rather outdated in a political environment strongly shaped by the internet (Landemore, 2014), especially by social media. Simply put: when citizens are sitting in front of a screen, it may be the screen of a computer, not necessarily that of a television. Although distributing 'likes' and sharing political content is surely far from the participatory ideal, it is not passivity. To give one example: the literature contrasts the mediatization of politics with the more recent 'viralization of politics' on social media. While the former was - from the viewpoint of politicians - about 'making media outlets communicate and trying to affect it [i.e. their communication]', the latter rather consists in 'making ordinary citizens communicate and trying to affect it' (Bene, 2017). The emergence of new plebiscitary techniques (Hendriks, 2020) also underscores the importance of conceptualizing the citizenry as a reactive rather than a passive entity.

We can say that the rising importance of social media over the past decade has in a certain sense made politics even more plebiscitarian by fostering direct interaction between leaders and followers (cf. Davies, 2020). This has been going hand in hand with the declining gatekeeper role of traditional media, a possible intervening actor in the leader-follower relationship: although numbers are not directly comparable, it is still illustrative that 'Trump had 17.6 million followers on Twitter and The New York Times [had] 1.2 million online only subscribers in the last quarter of 2016' (Enli, 2017, p. 53).

Next, let us look at how Green constrasts his ocular model with the vocal one. The latter sees the object of popular power in laws (that define norms and enact policies), the organ through which that power is exercised in the decisions where the voice of the people is heard and adopts the autonomy of the people (living under self-authored laws) as the critical ideal of democracy. The role of leadership in this vision is to educate the autonomous citizenry - capitalizing on Green's metaphor: like a vocal coach - to help the people in autonomous decision-making.

Contrary to the vocal view, the ocular model sees the object of popular power in the person of the leader: the great majority of the citizenry are interested in the character of their leaders rather than in specific policies. The popular gaze, an empowered form of sight, becomes the organ through which this power is exercised. This means that Green envisions something like an inverted panopticon (Botting, 2014), a 'synopticon' (Green, 2014), where constant surveillance by the many conditions the conduct of the few. His proposed critical ideal that replaces autonomy is that of candor, referring 'to the extent to which the conditions of a leader's public appearance are outside the control of the leader him- or herself' (Green, 2010, p. 181). In his ocular model, the Weberian notion of the charismatic relationship between the leader and followers assumes a more specific meaning: 
popular recognition is equated with charismatic leaders 'attain[ing], undergo[ing], and endur[ing] the public gaze' (Green, 2010, p. 148).

But who exactly is the subject of this disciplining sight? Who is the gazer? Green conceptualizes that entity as the People (with a capital P), claiming that thinking within the ocular model can restore the latter as a meaningful concept of collective identity (Green, 2010, pp. 27-29, 62-63, 138-139, 204-211). To be sure, his account of the People is not a will-based, Rousseauist one - he very well recognizes the potential totalitarian implications of that view. In his interpretation, individuals that make up the People are connected by their experience of passivity, spectatorship, being 'citizens-being-ruled', and their common interest that follows from this experience. We could also say that the People comes into being through citizens seeing themselves as set opposed to political leaders. This shared experience and recognized common interest, as Green argues, 'could function as a true source of unity, transcending partisan struggles and the outcomes of particular contests' (Green, 2010, p. 28, our emphasis). It is not difficult to see that facing a monolithic gazer in a synopticon has much stronger disciplining power than being observed from a bundle of contesting partisan perspectives.

The above notion of the People is the second problematic point of Green's theory. As some critics have already explored (Abbey, 2014; Schwartzberg, 2014), envisioning the (capitalized) People as a single collective entity is empirically untenable and theoretically dubious, since it downplays the role of pluralism and partisanship. Naturally, Green does not deny political pluralism, but he seems to hope that the glue that would hold together the People is stronger than adhesion to leaders and group-mentality.

However, this hope is problematic in the light of recent empirical trends that show the robust strengthening of partisan group mentality and identity-politics. First, increasing political polarization is taking place in contemporary democracies (Achen and Bartels, 2017; Down and Wilson, 2010; Iyengar et al., 2012; Lupton et al., 2017; Moral, 2017; Patkós and Szántó, 2021). Second, strong partisanship and increasing political polarization enhance citizens' emotional attachment to their leaders and the emotional stake of their victory, and this affects how they judge leaders' trustworthiness or candor (Achen and Bartels, 2017; Körösényi, 2013; Mason 2018). Third, political polarization is reflected in political homophily, i.e. in increasing unwillingness to make social contact with people from the other side (neighbourhood, friendship, dating, and marriage) (Mason, 2018, p. 55): the home becomes 'a political fortress' (Iyengar et al., 2018). Fourth, partisanship and polarization exert a powerful influence even on the assessment of factual matters. Achen and Bartels (2017, p. 269) find that partisan loyalties color citizens' views not only about candidates and issues, but even about objective facts. For example, in US politics strong partisan group-identity generates 'motivated reasoning' (Mason, 2018, p. 3), through which 'partisans seek out information with congenial slant and sincerely adopt inaccurate beliefs that cast their party in a favorable light' 
(Petersen and Iyengar, 2020, p. 133). Finally, as partisan identity becomes a social identity (Mason, 2015; West and Iyengar, 2020), it is not the issue-position of citizens that moulds their party preferences, but the other way around (Achen and Bartels, 2017, p. 310; cf. Kinder and Kalmoe, 2017). The increase in the strength of partisan polarisation takes place without an increase in the extremity of issue positions (Mason, 2015, p. 129). In this identity-based democracy '[v]ictory ... becomes more important than policy outcomes' (Mason, 2018, p. 23).

Faced with these empirical trends, a realist model of PLD acknowledges that the spectacle does not evolve in front of the disciplinary gaze of a single People, as Green assumes in his ocular model, but in front of the eyes of a politically divided and biased citizenry. Here, the role of the spectacle is exactly the reinforcement of the horizontal (partisan) division between political camps, which undermines the disciplinary gaze of the people.

Here, we may proceed to the third problematic point of Green's theory: it does not only overestimate people's capacity to control politicians, but at the same time, it underestimates political leaders' capacity to control the conditions of their public appearance and to shape citizens' political views (cf. Achen and Bartels, 2017; Urbinati, 2014, pp. 202-203). Although Green acknowledges that 'candor is a scarce commodity' in contemporary mass politics, he claims that this does not undermine its role as a realistic critical ideal (Green, 2010, p. 130). We do not wish to challenge the idealizing step itself but argue that a realistic theory should consider more thoroughly the empirical trends that make the envisioned critical ideal less likely to be realized. Such trends, as shown below, have multiplied in recent years.

As for leaders' capacity for manipulation, some have taken traditional stateowned television and radio channels under their strict political control and/or have bought up commercial media. Some leaders have presented themselves directly, but not under candid circumstances: like Hugo Chávez in his TV show (which, despite live phone calls, was staged and primarily aimed at mobilizing followers), or Viktor Orbán in his weekly radio interviews (where he is always interviewed by a loyal journalist). In a similar vein, Tony Blair reduced the weekly number of prime minister's question time sessions in parliament. Others, like Boris Johnson, Donald Trump, and Viktor Orbán exclude 'hostile' media outlets' journalists from their press conferences and communicate directly to their followers in social media messages. Additionally, leaders might try to 'simulate' candor, as in the case of Johnson's People's PMQs, where he answers preselected questions from the electorate; or Justin Trudeau's PR stunts, designed to seem spontaneous. Either way, politicians make strong efforts to control the circumstances of their public appearance and try to evade the circumstances of candor.

New technological opportunities, like big data analysis and more effective microtargeting, provide further opportunity to tailor messages to the attitudes of specific groups, and to shape their preferences through it (Chester and 
Montgomery, 2017). These tendencies are especially important since Green emphasizes that the empowered gaze is only possible when the People "can both observe the few without being observed in turn by them and when what it gets to see is not preprogrammed or rehearsed but constitutive of a genuine type of surveillance' (Green, 2010, pp. 139-140). Instead of pointing towards a synopticon, the new technological opportunities may rather open the possibility of a new panopticon. While the changing technological environment (e.g. because of the new plebiscitary techniques noted earlier) is seemingly more democratic and inclusive, it may in fact increase citizens' exposure to manipulation and weaken the possibilities of democratic control.

It seems that, despite its merits of uncovering the flaws of the vocal model and offering a coherent and theoretically substantiated perspective on contemporary democracies, Green's theory falls short of his proclaimed goal of realism (2010, pp. $24,29,68)$, as it is overly optimistic about the possibility of popular control. In the next part of the article, we aim at drawing the contours of an alternative, more realistic conception of plebiscitary democracy.

\section{Towards an Alternative Conception of Plebiscitary Democracy}

\section{The appropriate metaphor}

Following Hans Blumenberg (2010, Introduction), we may see metaphors as inexhaustible catalysts or 'nutrient solutions' of conceptual thought and theorybuilding. Through analyzing metaphors, he notes that we can 'burrow down to the substructure of thought, the underground'. Based on these considerations, we first identify the central metaphor of Green's plebiscitarianism, and then substitute it with one that is a better fit for contemporary circumstances. We then move on to the conceptual elaboration of our more realistic version of PLD.

As one of Green's critics observes, he reconfigures the Weberian theory of plebiscitarianism through the lens of the theater (Fitzgerald, 2015a, p. 308; 2015b, p. 51). Identifying two problems with this metaphor will help us find a more appropriate one. The first problem is a tension in Green's use of the metaphor: throughout his book, he seems to envision passive spectators sitting in the theatre. Nevertheless, at some point in Green's argument, they seem to become active, coming onto the stage and becoming the protagonists themselves (Fitzgerald, 2015a; 2015b, pp. 49-54; Tønder, 2015). The second problem is the supposedly unified reaction of the audience at the end of the play (cheering or booing), which in some authors' eyes seemed a good parallel of the binary logic (yes or no, acclamation or declamation) of plebiscitarianism (Rasch, 2019, pp. 133-135). However, it is exactly this supposedly unified response that limits the usefulness of 
the theater metaphor, because it underplays the role of divisons and political polarization within the citizenry.

If we are looking for a more appropriate metaphor for contemporary plebiscitary politics, we must look for one that leaves room not only for a less disciplined (i.e. at least reactive rather than passive) audience, but also for various spectatorial perspectives, different opinions about a performance (i.e. polarization and partisanship dividing spectators). We might think of sports metaphors - that the empirical literature often invokes in passing - as candidates. If we take seriously the empirical trends in voter behavior neglected by Green's approach, the consequence is that 'a partisan behaves more like a sports fan than like a banker choosing an investment' (Mason, 2015, p. 129). And the alignment of sports fans, to borrow from social psychologists, can often be 'tribal' (Clark et al., 2019; cf. Finkel et al., 2020), which can lead them to act as 'hooligans', as 'rabid sports fans of politics' (Brennan, 2016, p. 5).

More specifically, we might think of contemporary soccer games between rival teams, where a large number of spectators are ultras or even 'soccer hooligans'. Applied as a metaphor, this captures not only the opposed perspectives and deep divisions among spectators, but also that their reactions to the events on the playing field (such as singing and booing, not to mention pyrotechnics and spectator violence during a game) might make an impact. Or we can cite the classical example of the ill-famed Byzantine chariot-races, where spectators were deeply divided between the 'blues' (venetoi) and the 'greens' (prasinoi), the divisions often resulting in factional extremism and violence.

These metaphors incorporate the divided, polarized nature and the reactive role of the audience. In other words, they depict plurality not only in the leaders' competing visions, but also in the citizenry; and they leave room for true interactions between actors and spectators. Additionally, they also show one of the ultimate challenges of PLD in a polarized environment: to secure that the audience peacefully accepts the result of the race, and neither camp resorts to factional violence, as this would violate the core value of democratic minimalism, namely peaceful conflict-resolution (Przeworski, 1999).

\section{Conceptual elaboration: three pillars of PLD}

After grasping metaphorically what plebiscitary democracy might be like under contemporary circumstances, in this part we elaborate conceptual starting points for our theoretical alternative. We structure our argument along the features of Green's ocular model, focusing on three key points where our ideas differ from his: the representational nature of PLD, the voice of citizens as a veto power, and the critical ideal of competition (see Table 1). 
Table 1: Green's two models and our proposition of PLD.

\begin{tabular}{llll}
\hline & Vocal & $\begin{array}{l}\text { Ocular (Green's plebiscitary } \\
\text { democracy) }\end{array}$ & PLD \\
\hline $\begin{array}{c}\text { Nature of the } \\
\text { theory }\end{array}$ & representational & post-representational & representational \\
$\begin{array}{c}\text { Object of popular } \\
\text { power }\end{array}$ & law & leader & leader \\
$\begin{array}{c}\text { Organ of popular } \\
\text { power } \\
\begin{array}{c}\text { Critical ideal of } \\
\text { democracy }\end{array}\end{array}$ & $\begin{array}{c}\text { autonomy of } \\
\text { citizens }\end{array}$ & candor of leaders & $\begin{array}{c}\text { voice as veto power } \\
\text { (acceptance/rejection) }\end{array}$ \\
\hline
\end{tabular}

Source: Based on Green (2010, pp. 127-134) and supplemented by the authors

\section{Representation}

We argue that plebiscitarianism should return to the representational paradigm and to the vocal model of popular control. While Green's ocular model of popular empowerment is not realistic, there is indeed an important place for the ocular dimension, however, as the terrain for creative leadership rather than for popular control. Because of its aesthetic connotations, the notion of representation can be especially useful in theorizing the constitutive role that creative leadership plays in forming followers' identity. After showing this, we argue that popular control should be thought of in vocal terms, although differently than in Green's vocal model.

Not denying that some of the theoretical problems Green raises concerning representation (primarily regarding the realizability of accountability - Green, 2010, pp. 17-19) are as grave as they might seem, his conclusion to throw out representation as a conceptual ballast is premature. His claim that there is an old metaphysical picture of an expressive subject and a mirroring object lurking behind the representative claim is certainly true for some approaches, but - not to mention earlier examples - already Weber saw more room for creativity in the representative process, describing the representative 'not as the servant but as the chosen "master" of his voters' (Weber, 1978, p. 1128). Recent constructivist and performative theories of representation complement this view by arguing that the role of representation is constitutive in articulating the identity of the represented (Disch, 2015; Saward, 2010; 2017; Casullo, 2021; cf. Laclau, 2005), similarly as the perspective of the painter is constitutive of a landscape painting (Ankersmit, 1996; 2002). This vision of representation avoids the metaphysical trap that Green warns us about, and promts us to ask not about the 'correctness' of a representation, but rather about its 'artistic value' and constitutive role.

But how exactly should representation be conceptualized in PLD? While the original Weberian view sees representation as imputing the actions of specific 
group or organizational members to the whole group or organization (Weber, 2019, pp. 127, 437), we argue that under contemporary circumstances, representation takes on a double meaning in PLD. To borrow a distinction from Fossen (2019), beside the representative agency Weber talks about, representation as portrayal is of equal importance in PLD today. We analyze these two aspects in turn.

As Fossen (2019) shows, representation as portrayal has a triadic structure: it is representing something as something, like in portrait- or landscape-painting (cf. Ankersmit, 1996; Saward, 2010). By picking out a referent (a group: either the leader's followership or the whole citizenry) and characterizing it, the process of portraying constitutes identity (Fossen, 2019, p. 833). Therefore, representation means much more than mere mirroring: it is a space where the creativity of leadership can unfold. Leaders can act as 'entrepreneurs of identity' (Reicher and Haslam, 2016). Additionally, as Saward emphasizes (2010, pp. 46-48), leaders portray not just their followership, but also themselves, thereby establishing their political persona. It is the nature of the fit between these two portrayals (between the identity of the group and the leader's political persona) that distinguishes PLD from other settings: the leader must be seen as a prototypical member of the group, i.e. an ordinary man, 'one of them', yet still extraordinary (Haslam et al., 2011; Hogg et al., 2012; Reicher and Haslam, 2016). As the social psychological accounts cited emphasize, complementing the original Weberian view of charisma, this is the best way to be perceived as charismatic by the followers.

Let us highlight this process with a somewhat fictionalized example. Imagine that de Gaulle portrays his followers as 'true French'. He portrays himself also as 'true French', but additionally as someone who - unlike anyone else - has more specific attributes: a special connection with the French nation, outstanding political judgement, and therefore a historical role and responsibility. The first step constructs an identity for his followers (either through formulating the mentioned claim in speeches, or through the appropriation of selected French national symbols for his movement), thereby he articulates a group (the Gaullist movement) from individuals. Then, he constructs a group-prototypical persona for himself: he is congenial to his followers, but still different from them, and not merely in having a greater share from a common attribute (that would only make him the 'truest Frenchman'). In the construct of his persona, he also has exceptional qualities. Therefore, similarity to his followers and difference from them are intertwined in his charismatic appeal. Put differently: his portrayed political persona resembles the constructed identity of the followers only at certain points, selected by the leader; the relationship between the two constructs is synecdochal (Casullo, 2021). Naturally, the activity of portraying may comprise discursive practices, as well as images, performances, and spectacles - this underlines the role of the ocular realm in the creative process of representation.

Although identity construction brings individuals in the group together, this is usually accompanied by a divisive and polarizing component: the positive identity 
of a group is constituted by contrasting it with a radically different other. This is a point both emphasized by the social ontology underlying constructivist theories of representation (cf. Laclau and Mouffe's notion of 'constitutive outside' - Mouffe, 2000), and by the empirical research results of social psychology: the emergence of an identity-group (an ingroup) is accompanied by the appearance of an outgroup (Mason, 2015; 2018; Achen and Bartels, 2017). Although the degree of polarization brought about by this logic of identity construction might vary from case to case, charismatic leaders might be especially prone to polarize (cf. Körösényi et al., 2020 , ch. 3). This is because of the instability of the charismatic appeal: according to Weber, such leaders are sought especially in crisis situations and external threats (Weber, 1978, p. 1134). If there is no such threat at hand, charismatic leaders might try to portray outgroups as posing an existential challenge to the community, merely to maintain their appeal.

Let us now consider the other sense of representation, namely representative agency. Following Fossen (2019) once again, representation here has a dyadic structure: it means simply representing someone or something, as a lawyer represents a client before the court, or as PMs represent their country at international negotiations. The minimal or formal sense of such kind of representation is that the representative is regarded as authorized to act in the name of the represented, therefore - in Weberian terms - the deeds of the representative are imputed to the represented. ${ }^{2}$ While a leader can certainly be authorized to act in the name of a diverse range of groups (e.g. a political party or movement), representative agency plays the most important role on the national level. In PLD, a successful plebiscite is interpreted as an authorization not merely by the leader's followership that voted for her and helped her to attain a majority, but by the 'sovereign people' (Weber, 2019, p. 407). As in such a setting, elections also work as plebiscites about leaders, the primary representative who gets the authorization is not the representative assembly or parliament anymore, but the leader as chief executive (Körösényi, 2005).

However, if we want to move beyond the notion of electoral democracy, and make sense of the citizenry as an entity that may react to certain measures already before the next election, we have to add an important point to this formalistic sense of representative agency endorsed by Weber (cf. Pitkin, 1967, pp. 39-44, 141-143): the leader should be careful not to spread the feeling that she blatantly neglects the task of acting for the people that authorized her, because that may lead to significant popular resistance. The attitude of 'Shut your mouths and obey me' might work in most cases, but not always. Where these limits of leadership voluntarism lie is well beyond the scope of this article - but the notion that there are such limits is essential to the notion of popular veto power, elaborated in the next section.

It is important to note that while the top-down articulation of the followers' identity (representation as portraying) is the result of the leader's creativity, the 
fiction of the 'sovereign people' comes emerges rather because of the need for collective action and the resultant institutional necessity, the 'One to All' (one government to all citizens) architecture of our political institutions (Saward, 2010, pp. 90-91). This fictional character of the 'sovereign people' stands in stark contrast to Green's view about the capitalized People as a meaningful and realizable collective identity.

\section{Voice as veto power}

After the above discussion, the following question arises: if representation leaves such a great 'aesthetic gap' (Ankersmit) for leaders, and if they are in Weber's words the "chosen "masters" of their voters, how can popular control be conceptualized in PLD? We argue that although there is ample room for the leader's creativity, representation in the sense defined above still provides an unambiguous location for popular power. In contrast to the People's gaze, i.e. the organ of popular power in Green's ocular version of plebiscitary democracy, in the concept of PLD that we explore, it is the citizens' 'voice'. However, we do not interpret voice as a decision-making (legislative) power (as Green does in constructing the vocal model), but as plebiscitary veto power. This is the locus of popular power in PLD: the people's power of approval (or rejection) of incumbents.

The conceptualization of popular control in PLD through citizens' plebiscitary veto power is a rather modest realistic claim, which is in concordance with empirical research results (Chong, 2013; Mason, 2015; 2018; Achen and Bartels, 2017; Kahan, 2017; Kinder and Kalmoe, 2017). It does not require citizens to be rational and autonomous agents (as in the vocal model depicted by Green): motivated reasoning, partisan identity and manipulation by political leaders may well find their place in it. It does not afford an efficient feedback mechanism either, which is provided both by the mandate and the accountability model of representation. It guarantees neither the policy responsiveness of the government, nor an efficient working of Friedrich's rule ${ }^{3}$ that is ensured through reliable ex post facto judgment made by citizens of the incumbent's record (Manin et al., 1999, pp. 40-44). This means that popular power is unable to evoke good public policies, and veto power means accountability at most in the weakest, metaphorical sense.

Even if veto power in PLD is a diminished form of popular control, it is not insignificant. Although it does not provide permanent surveillance that might place constant a burden on leaders (as in Green's ocular model), it affords citizens ultimate control over their rulers: they might approve and reject them on a regular basis (Schumpeter, 1987, pp. 272-289). Elections and the accompanying veto power manifest the 'popular will' vis-à-vis their leaders, and thereby still render the incumbent's position somewhat uncertain, which is an important characteristic of democratic politics (Przeworski, 1991). Although they do not judge the incumbent's record in an autonomous way, political leaders' actions can still 'strike a nerve', resulting in a loss of support among their electorate (metaphorically: 
supporters booing their own team), and the people giving authorization to someone else at the next election.

It is important to note that between elections voice as veto power may manifest itself in a softer form: the feeling that the elected leader blatantly neglects the task of acting for the people may lead to significant popular protests, which in turn may further weaken her claim of representing the people. As David Runciman puts it: while abstractions cannot themselves protest, if sufficient numbers of individuals object on its behalf, then it becomes impossible for a government to continue to claim to represent the people' (Runciman, 2007, p. 101). In the end, this process may trigger the withdrawal of (proposed) government policies (see, e.g. Körösényi et al. 2020, pp. 49, 125-127).

Additionally, note that the concept of veto power is interconnected with citizens conceptualized as reactive, rather than as passive agents (as it is assumed in electoral democracy): even temporarily heightened levels of political participation may fit within the theoretical frame of PLD if they are triggered by the political leaders' actions.

\section{Competition}

So far, we have examined the leader-follower relationship, but the horizontal dimension of the relationship between leaders is also crucial for PLD to have some normative merit. This relationship should be that of competition, which means prima facie that the election results should be uncertain before the election (Schumpeter, 1987; Przeworski, 2018, ch. 1). However, this Schumpeterian view of competition, adopted from economics, may be rightly criticized for taking the edge off political conflict (cf. Mouffe, 2000). Weber's harsher characterization of the competitive element as struggle $(\text { Kampf })^{4}$ fares better in this respect, but it still neglects a crucial point present in contemporary social constructivist theories: the role of collective identities (Laclau, 2005; Mouffe, 2013, ch. 1). Arguably, the role of such identitities is even stronger in the polarized contemporary environment. Therefore, competition should not be seen in economic terms, but rather as a broader category which encompasses not only conflicts of interest, but also takes note of how conflicting collective identities are construed. The sports metaphor outlined earlier fares better in this respect than the analogy of economics because it depicts exactly such competitions. At the same time, it points out an important fact that social constructivist theories often neglect: the primary actors of these conflicts are individuals who stand for groups (charioteers, soccer players, or political leaders). Although Weber's and Schumpeter's methodological individualism blinded them to questions of collective identity, it made them especially sensitive to the role of leadership in the democratic process. Fusing the two horizons, i.e. the Weberian-Schumpeterian and the contemporary social constructivist, is essential in conceptualizing PLD under contemporary conditions. 
We will demonstrate below that a certain interpretation of competition can function as a more realistic critical ideal than candor and may save PLD from being a 'sham democracy' (Green, 2010, p. 122) without any normative content. By calling it realistic, we mean that it is not rendered illusory by the contemporary tendencies analyzed in the article. However, we might add - supplementing and refining the original Weberian theory - that there is no guarantee for real competition in a plebiscitary regime - it is enough to think of Bonapartism, a case Weber treats in Economy and Society.

Although competition is a minimalist normative criterion, it is by no means complacency; it may still guide political judgment and action, as Przeworski (2018) emphasizes. ${ }^{5}$ We will analyze four aspects of competition that may have political value, while - in a realist spirit - pointing out certain trade-offs between those values and indicating the places where further theoretical work would be needed.

First, competition in a regulated environment provides a peaceful method for leadership selection and conflict-resolution, as emphasized by the minimalist conception of democracy Joseph Schumpeter (1987) and Adam Przeworski (1999; 2018) explore. Przeworski marshals at least three arguments about how competitive elections can function as a method of peaceful conflict-resolution. The first could be called an expressive argument: although he maintains that participation does not induce compliance on the side of voters (Przeworski, 1999, p. 48), but at the same time insists that 'being able to vote for a party that represents their views' (Przeworski, 2018) is what they value most in elections, and this is even more important than the end result. This argument is complemented with the second argument, which is about hope: in the case of a defeat, there is the possibility that my party will be victorious next time. The sports-metaphor is apt here, and Przeworski invokes it explicitly (2018), likening the 'siren song' of elections to disappointed soccer fans' hopes that next year their team will win the competition. Finally, Przeworski's third and perhaps best-known argument is that elections are like 'flexing muscles', reading the chances of an eventual war, where it would be foolish for the loser to disregard the result (1999, p. 48; 2019, p. 162). These mechanisms, in his view, ensure that in an election the losing side will respect the final result.

Naturally, Przeworski does not claim that electoral rules are neutral, or that incumbents do not try to manipulate those rules. Politics, in contrast to games and sport, is not just playing within set rules, but is also about the setting of rules (Philp, 2007, p. 10). Przeworski's answer to this problem is to invoke a kind of democratic equilibrium, where the incumbents do not alter the rules to such an extent as to induce a rebellion in the opposing camp (1999, p. 46). This argument, however, faces new challenges under contemporary circumstances. While Trump's loss of the popular vote despite his 2016 election victory only questions Przeworski's third argument (not to mention that this was not an unprecedented case), mutual accusations between Trump and Biden in the 2020 campaign concerning possible 
future election frauds, and Trump's unwillingness to admit his defeat after the election might challenge on a deeper level the entire framework of peaceful conflict resolution. A more elaborate theory of PLD will need to deal with this problem in detail.

Second, the leaders' competition for votes and regular elections provides a mechanism for a meritocratic selection of political leaders, namely, the approval of candidates with certain excellences. We know from Bernard Manin's (1997) work that elections do have an 'aristocratic' nature, compared to the selection of delegates by the democratic method of lot, as people naturally aim to choose a qualitatively better person than themselves to represent them. Similarly, Weber was also very much concerned with the meritocratic way of leaders' selection; having made a comparative review of the democracies of his time, he found it in PLD. Plebiscitary politics, i.e. competition of demagogue politicians directly for citizens' vote, nurtures leaders' extraordinary, charismatic inner qualities that distinguish a conviction politician with an inner 'calling' from a professional one (Berufspolitiker) without such a 'calling' and conviction. Being an expert in struggle, having visionary qualities, and taking personal responsibility are further key excellences Weber connected to PLD (cf. Green, 2010, pp. 154-156). Nevertheless, the question arises if under contemporary conditions PLD is still able to nurture excellences. It is quite right to raise doubts at this point: while the excellence of chariot-racers and soccer teams does not depend on the spectators' opinions (an outstanding team can beat the opponent even in an away match, where they are constantly booed), in politics the spectators' vote is decisive. If they are biased by partisan loyalty, if a political camp votes for their leaders no matter how they perform, as it has become quite common in polarized and 'sectarian' contemporary politics (Achen and Bartels, 2017; Brennan, 2016; Kahan, 2017), competition seems robbed of most of its meritocratic effect. ${ }^{6}$ However, some of that effect may still be retained: even when the electorate is polarized and vulnerable to manipulation, it seems unlikely that a candidate could win an electoral competition without certain excellences, such as endurance, rhetorical skills, commitment, toughness, and others.

Third, competition has an integrative function: although the mass of spectators may be deeply divided, leaders do not merely conform to existing identities. They also craft and mold them, acting as 'entrepreneurs of identity', and featuring their competitors as an outgroup that helps in cementing identities (cf. Reicher and Haslam, 2016; Haslam et al., 2011, pp. 137-164; Mason, 2018). For politics to work, the myriad of perspectives and interests must be integrated; it is a political value that a leader can contribute to this job. In PLD - in contrast to other theories the leader fulfills an integrative role through presenting a vision, thereby creating identity and mobilizing followers for collective aims (Mumford, 2006; Kiss and Szabó, 2018). Unification goes hand in hand with a certain degree of polarization: identity creation relies on constructing enemies, since defining 'them' specifies the 
identity of 'us' (cf. Mouffe, 2000, pp. 101-105; Laclau, 2005, pp. 83-93; Körösényi et al., 2020, pp. 50-61).

Arguably, there is a potential trade-off here between two values of competition: ordering the chaos of the radical plurality of viewpoints that is necessary for effective political action can easily lead to radical polarization, to two camps that 'look like granitic strongholds' (Urbinati, 2014, p. 160) - a scenario that diminishes meritocratic selection, as we have seen above.

Finally, competition can also function as an antidote to depoliticization (pace Scott, 2018). In Weberian terms, charismatic leaders widen the issues of competition, challenge the existing status quo, and subvert institutionalized norms. In this competition, Weber saw the potential counterweight to the rationalization and bureaucratization of his age. Competition may have an analogous role in the twenty-first century, by countering tendencies like post-democracy (Crouch, 2004), or the hollowing out of democracy (Mair, 2013). To name some examples: PLD may bring politics back into spheres that had earlier slipped out of democratic political control due to various emerging tendencies such as globalization accompanied by neoliberal ideology, the growing power of international organizations and the European Union, non-majoritarian institutions, technocratic decision-making, multilevel-governance, and the convergence or cartelization of parties, as well as the decline of party competition.

However, at this point, we face another trade-off: the potential gains of questioning the rules of the game threaten to undermine competition as a peaceful conflict resolution among agreed rules; it seems that repoliticization might subvert the minimalist conception of democracy. Weber was also preoccupied with this problem of stability and subversion (cf. Weber, 1994), and, frankly speaking, he never offered a convincing solution. Perhaps a first step forward would be to differentiate between various kinds of rules and norms: those that are central to upholding the minimalist conception of democracy (e.g. electoral rules), and those that are not (e.g. modes of speech and political style).

\section{Conclusion}

In this article, we have shown why PLD might be an appropriate tool for analyzing and understanding contemporary democratic politics. We are witnessing a return of the 'Weberian' (i.e. plebiscitary) leaders. We have also argued that these conditions magnify the empirical and theoretical problems in Jeffrey Green's vision of plebiscitary politics that have already been criticised in the literature. We have shown that Green's version of plebiscitarianism underestimates the role of political division and polarization within the electorate, as well as the tools leaders have at their disposal to influence, mould and structure the electorate. We contend that with the growing role of social media over the past decade, his conceptualization of the 
citizenry as a passive entity has become less convincing. Finally, we argue that his theory is too optimistic about leaders' incentives. Taken together, these problems render Green's vision of plebiscitarianism almost as empirically unrealistic as the vocal model of democracy he rightly criticizes.

As a first step towards formulating a theory of PLD that can claim to be realistic, we propose that a certain type of sports event (where spectators are deeply divided and are attached on an identity-base to teams) is a more proper metaphor to understand PLD under contemporary conditions than a theater where actors face a passive, monolithic audience. Additionally, we have laid out three starting points for a more detailed future plebiscitary theory: the return to the concept of representation with a specific content; the return to the voice of the citizenry, conceptualized not as a decision-making, but as a veto power; and a return to the notion of competition, which could serve as a more realistic critical ideal than Green's concept of candor. We have described competition as incorporating four more specific values (peaceful conflict-resolution, meritocratic selection, integration, and repoliticization) that form the normative core of PLD. Following these recommendations would mean returning from Green's most innovative, yet not sufficiently realistic vision to a more 'traditional' view of plebiscitary politics, which is at the same time attuned to various criticisms it has encountered in recent decades (be that the criticism coming from social constructivist approaches or postrepresentationalism) and which provides a modest, but more realistic critical ideal.

Naturally, our positive, alternative conception of PLD presented here is only a first step towards a more elaborate theory. What we tried to demonstrate in the second half of the article is that in its modified form PLD can help us analyze contemporary political phenomena, such as the heightened role of identity politics and partisanship often resembling sectarianism and tribalism. However, there is still much work to do: the values of competition in PLD and their possible tradeoffs should be elaborated in depth, with their empirical conditions thoroughly assessed. This is especially important since plebiscitary politics presents us with a twin danger: first, it does not necessarily meet even minimalist conceptions of democracy (competition being the feature that distinguishes PLD from a version of Bonapartism attuned to Ludendorff's taste); second, in a polarized environment of identity politics, competition might easily transgress the boundaries of peaceful conflict resolution. An elaborate theory of PLD should address these twin dangers with appropriate care. 


\section{Author Biographies}

Gábor Illés is a research fellow at the Centre for Social Sciences, Eötvös Loránd Research Network (ELKH), and a lecturer at the Faculty of Law, Eötvös Loránd University. His research interests include political leadership, political representation, and realism in political theory.

András Körösényi is a research professor at the Centre for Social Sciences, ELKH, and professor of political science at the Faculty of Law, Eötvös Loránd University. His research interests include theories of democracy, political leadership, and plebiscitary politics.

\section{Acknowledgements}

We would like to thank our colleagues at the Institute for Political Science (ELKH Centre for Social Sciences), the two anonymous reviewers, and the editors of CPT for their most helpful critical remarks on earlier versions of the text. The usual disclaimer applies. This work was supported by the National Research, Development and Innovation Fund [K 128139].

\section{Funding}

Open access funding provided by Centre for Social Sciences.

\section{Open Access}

This article is licensed under a Creative Commons Attribution 4.0 International License, which permits use, sharing, adaptation, distribution and reproduction in any medium or format, as long as you give appropriate credit to the original author(s) and the source, provide a link to the Creative Commons licence, and indicate if changes were made. The images or other third party material in this article are included in the article's Creative Commons licence, unless indicated otherwise in a credit line to the material. If material is not included in the article's Creative Commons licence and your intended use is not permitted by statutory regulation or exceeds the permitted use, you will need to obtain permission directly from the copyright holder. To view a copy of this licence, visit http:// creativecommons.org/licenses/by/4.0/. 


\section{Notes}

1 Our use of the word 'realism', we believe, is consonant with Bernard Williams' claim that theorizing 'cannot escape starting from what is at hand, from the kinds of life among which it finds itself. Like everyone else, it must accept the truth that in the beginning was the deed' (Williams, 2005, pp. 23-24).

2 As per Pitkin, authorization is a formalistic understanding of representation. That someone is authorized to act 'means that he has been given a right to act which he did not have before, while the represented has become responsible for the consequences of that action as if he had done it himself' (Pitkin, 1967, pp. 38-39).

3 According to Friedrich's rule, incumbent leaders anticipate voters' reactions to their policies and adjust them accordingly (Friedrich, 1963).

4 'The decisive point is that for the task of national leadership only such men are prepared who have been selected in the course of the political struggle [Kampf], since the essence of all politics is struggle [Kampf]' (Weber, 1978, p. 1450; Weber, 1921, p. 210).

5 We side with this more charitable view of minimalism, contrary to the interpretation that Green (2016, pp. 20-26) puts forward.

6 'Political sectarianism' is defined as a kind of 'moralized identification with one political group against another' (Finkel et al., 2020, p. 533).

\section{References}

Abbey, R. (2014) Lots'a gotcha moments for the deciders: Jeffrey Green's eyes of the people (Symposium on Jeffrey E. Green's The Eyes of the People: Democracy in an Age of Spectatorship ed. by Richard Avramenko and Melissa Schwartzberg). Political Theory 42(2): 202-206. https://doi.org/ 10.1177/0090591713516414.

Achen, C.H. and Bartels, L.M. (2017) Democracy for Realists. Why Elections Do Not Produce Responsive Government. Princeton: Princeton University Press.

Ankersmit, F.R. (1996) Aesthetic Politics: Political Philosophy Beyond Fact and Value. Stanford: Stanford University Press.

Ankersmit, F.R. (2002) Political Representation. Stanford: Stanford University Press.

Bene, M. (2017) Sharing is caring! investigating viral posts on politicians' Facebook pages during the 2014 General Election Campaign in Hungary. Journal of Information Technology \& Politics 14(4): 387-402. https://doi.org/10.1080/19331681.2017.1367348.

Blumenberg, H. (2010) Paradigms for a Metaphorology, trans. R. Savage. Ithaca, NY: Cornell University Press and Cornell University Library.

Botting, E.H. (2014) Watching the Burkean Trustee and internet politics through the lens of Jeffrey Green's the eyes of the people (Symposium on Jeffrey E. Green's The Eyes of the People: Democracy in an Age of Spectatorship). Political Theory 42(2): 197-201. https://doi.org/10.1177/ 0090591713516414.

Brennan, J. (2016) Against Democracy. Princeton: Princeton University Press.

Casullo, M.E. (2021) Populism as synecdochal representation. In P. Ostiguy, F. Panizza and B. Moffitt (eds.) Populism in Global Perspective. A Performative and Discursive Approach. New York: Routledge, pp. 79-94. 
Chester, J. and Montgomery, K.C. (2017) The role of digital marketing in political campaigns. Internet Policy Review 2: 89. https://doi.org/10.14763/2017.4.776.

Chong, D. (2013) Degrees of rationality in politics. In L. Huddy, D.O. Sears and J.S. Levy (eds.) The Oxford Handbook of Political Psychology. 2nd edn. Oxford: Oxford University Press, pp. 96-129.

Clark, C.J., Liu, B.S., Winegard, B.M. and Ditto, P.H. (2019) Tribalism is human nature. Current Directions in Psychological Science 28(6): 587-592. https://doi.org/10.1177/0963721419862289.

Crouch, C. (2004) Post-Democracy. Cambridge: Polity Press.

Dalton, R.J. and Wattenberg, M.P. (2000) Parties without Partisans: Political Change in Advanced Industrial Democracies. Oxford: Oxford University Press.

Davies, W. (2020) Who Am I Prepared to Kill? The Politics of Like and Dislike. London Review of Books 30 July 2020 https://lrb.co.uk/the-paper/v42/n15/william-davies/who-am-i-prepared-to-kill, accessed 21 November 2020.

Disch, L. (2015) The 'constructivist turn' in democratic representation: A normative dead-end? Constellations 22(4): 487-499. https://doi.org/10.1111/1467-8675.12201.

Down, I. and Wilson, C.J. (2010) Opinion polarization and inter-party competition on Europe. European Union Politics 11(1): 61-87. https://doi.org/10.1177/1465116509353457.

Enli, G. (2017) Twitter as arena for the authentic outsider: Exploring the social media campaigns of Trump and Clinton in the 2016 US presidential election. European Journal of Communication 32(1): 50-61. https://doi.org/10.1177/0267323116682802.

Finkel, E.J., Bail, C.A., Cikara, M., Ditto, P.H., Iyengar, S., Klar, S., et al. (2020) Political sectarianism in America. Science 370(6516): 533-536. https://doi.org/10.1126/science.abe1715.

Fitzgerald, S. (2015a) Is there a role for spectators in democratic politics? A reflection on the theater metaphor in Green's 'ocular democracy.' Constellations 22(2): 302-313. https://doi.org/10.1111/ 1467-8675.12148.

Fitzgerald, S. (2015b) Spectators in the Field of Politics. Basingstoke: Palgrave Macmillan.

Fossen, T. (2019) Constructivism and the logic of political representation. American Political Science Review 113(3): 824-837. https://doi.org/10.1017/S0003055419000273.

Friedrich, C.J. (1963) Man and His Government: An Empirical Theory of Politics. New York: McGrawHill.

Green, J.E. (2010) The Eyes of the People. Democracy in an Age of Spectatorship. Oxford: Oxford University Press.

Green, J.E. (2014) Reply to critics (Symposium on Jeffrey E. Green's The Eyes of the People: Democracy in an Age of Spectatorship). Political Theory 42(2): 206-214. https://doi.org/10.1177/ 0090591713516414.

Green, J.E. (2016) The Shadow of Unfairness: A Plebeian Theory of Liberal Democracy. Oxford: Oxford University Press.

Haslam, S.A., Reicher, S.D. and Platow, M.J. (2011) The New Psychology of Leadership. Hove: Psychology Press.

Hendriks, F. (2020) Unravelling the new plebiscitary democracy: Towards a research agenda. Government and Opposition. https://doi.org/10.1017/gov.2020.4.

Hogg, M.A., van Knippenberg, D. and Rast, D.E. (2012) The social identity theory of leadership: Theoretical origins, research findings, and conceptual developments. European Review of Social Psychology 23(1): 258-304. https://doi.org/10.1080/10463283.2012.741134.

Iosifidis, P. and Wheeler, M. (2018) Modern political communication and Web 2.0 in representative democracies. Javnost—the Public 25(1-2): 110-118. https://doi.org/10.1080/13183222.2018. 1418962.

Iyengar, S., Konitzer, T. and Tedin, K. (2018) The home as a political fortress: Family agreement in an era of polarization. The Journal of Politics 80(4): 1326-1338. https://doi.org/10.1086/698929.

Iyengar, S., Sood, G. and Lelkes, Y. (2012) Affect, not ideology: A social identity perspective on polarization. Public Opinion Quarterly 76(3): 405-431. https://doi.org/10.1093/poq/nfs038. 
Kahan, D.M. (2017) Misconceptions, misinformation, and the logic of identity-protective cognition. SSRN Electronic Journal. https://doi.org/10.2139/ssrn.2973067.

Kalpokas, I. (2019) A Political Theory of Post-Truth. Cham: Springer.

Karvonen, L. (2009) The Personalisation of Politics: A Study of Parliamentary Democracies. Colchester: ECPR Press.

Kinder, D.R. and Kalmoe, N.P. (2017) Neither Liberal nor Conservative: Ideological Innocence in the American Public. Chicago: The University of Chicago Press.

Kiss, B. and Szabó, G. (2018) Constructing political leadership during the 2015 European migration crisis: The Hungarian case. Central European Journal of Communication 11(1): 9-24. https://doi.org/ 10.19195/1899-5101.11.1(20).1.

Körösényi, A. (2005) Political representation in leader democracy. Government and Opposition 40(3): 358-378. https://doi.org/10.1111/j.1477-7053.2005.00155.x.

Körösényi, A. (2013) Political polarization and its consequences on democratic accountability. Corvinus Journal of Sociology and Social Policy 4(2): 111-138.

Körösényi, A., Illés, G. and Gyulai, A. (2020) The Orbán Regime: Plebiscitary Leader Democracy in the Making. London: Routledge.

Laclau, E. (2005) On Populist Reason. London: Verso.

Landemore, H. (2014) Neither blind, nor mute: Why the people shouldn't give up on the voice (Symposium on Jeffrey E. Green's The Eyes of the People: Democracy in an Age of Spectatorship). Political Theory 42(2): 192-197. https://doi.org/10.1177/0090591713516414.

Lupton, R.N., Smallpage, S.M. and Enders, A.M. (2017) Values and political predispositions in the age of polarization: Examining the relationship between partisanship and ideology in the United States, 1988-2012. British Journal of Political Science 50(1): 241-260. https://doi.org/10.1017/ S0007123417000370.

Mair, P. (2013) Ruling the Void: the Hollowing of Western Democracy. London: Verso.

Manin, B. (1997) The Principles of Representative Government. Cambridge: Cambridge University Press.

Manin, B., Przeworski, A. and Stokes, S. (1999) Elections and representation. In A. Przeworski, S. Stokes and B. Manin (eds.) Democracy, Accountability and Representation. Cambridge: Cambridge University Press, pp. 29-54.

Mason, L. (2015) 'I disrespectfully agree': The differential effects of partisan sorting on social and issue polarization. American Journal of Political Science 59(1): 128-145. https://doi.org/10.1111/ajps. 12089.

Mason, L. (2018) Uncivil Agreement: How Politics Became Our Identity. Chicago: The University of Chicago Press.

Moffitt, B. (2016) The Global Rise of Populism. Stanford: Stanford University Press.

Moral, M. (2017) The bipolar voter: On the effects of actual and perceived party polarization on voter turnout in European multiparty democracies. Political Behavior 39: 935-965. https://doi.org/10.1007/ s11109-016-9386-0.

Mouffe, C. (2000) The Democratic Paradox. London: Verso.

Mouffe, C. (2013) Agonistics: Thinking the World Politically. London: Verso.

Mumford, M.D. (2006) Pathways to Outstanding Leadership: A Comparative Analysis of Charismatic, Ideological, and Pragmatic Leaders. Mahwah, NJ: Lawrence Erlbaum Associates.

Pakulski, J. and Körösényi, A. (2012) Toward Leader Democracy. London: Anthem Press.

Palonen, K. (2018) Submitting 'alternative facts' to debate: A Weberian perspective on post-truth politics. Redescriptions 21(2): 112-127. https://doi.org/10.7227/R.21.2.2.

Patkós, V. and Szántó, A. (2021) Does sophistication increase partisan bias? Evidence from a crossnational analysis. European Politics and Society 22(3): 359-373. https://doi.org/10.1080/23745118. 2020.1769941 . 
Petersen, E. and Iyengar, S. (2020) Partisan gaps in political information and information-seeking behavior: Motivated reasoning or cheerleading? American Journal of Political Science 65(1): 133-147. https://doi.org/10.1111/ajps.12535.

Philp, M. (2007) Political Conduct. Cambridge, MA: Harvard University Press.

Pitkin, H. (1967) The Concept of Representation. Berkeley: University of California Press.

Poguntke, T. and Webb, P. (eds.) (2005) The Presidentialization of Politics: A Comparative Study of Modern Democracies. Oxford: Oxford University Press.

Przeworski, A. (1991) Democracy and the Market. Cambridge: Cambridge University Press.

Przeworski, A. (1999) Minimalist conception of democracy: A defence. In I. Shapiro and C. HackerCordón (eds.) Democracy's Value. Cambridge: Cambridge University Press, pp. 23-55.

Przeworski, A. (2018) Why Bother with Elections?. Cambidge: Polity Press.

Przeworski, A. (2019) Crises of Democracy. Cambridge: Cambridge University Press.

Radkau, J. (2009) Max Weber: A Biography, trans. P. Camiller. Cambridge: Polity Press.

Rasch, W. (2019) Carl Schmitt: State and Society. London: Rowman and Littlefield.

Reicher, S. and Haslam, S.A. (2016) The politics of hope: Donald Trump as an entrepreneur of identity. In M. Fitzduff (ed.) Why Irrational Politics Appeals: Understanding the Allure of Trump. ABC-Clio: Santa Barbara, CA, pp. 25-40.

Runciman, D. (2007) The paradox of political representation. The Journal of Political Philosophy 15(1): 93-114. https://doi.org/10.1111/j.1467-9760.2007.00266.x.

Saward, M. (2010) The Representative Claim. Oxford: Oxford University Press.

Saward, M. (2017) Performative representation. In M. Brito Vieira (ed.) Reclaiming Representation: Contemporary Advances in the Theory of Political Representation. Abingdon: Routledge, pp. 75-94.

Schumpeter, J.A. (1987) Capitalism, Socialism and Democracy. London: Unwin.

Schwartzberg, M. (2014) Superhuman vision: Beyond the gaze (Symposium on Jeffrey E. Green's The Eyes of the People: Democracy in an Age of Spectatorship). Political Theory 42(2): 189-192. https:// doi.org/10.1177/0090591713516414.

Scott, A. (2018) (Plebiscitary) Leader democracy: The return of an illusion? Thesis Eleven 148(1): 3-20. https://doi.org/10.1177/0725513618800120.

Spoelstra, S. (2020) The truths and falsehoods of post-truth leaders. Leadership 16(6): 757-764. https:// doi.org/10.1177/1742715020937886.

Tønder, L. (2015) Seeing and being seen: A response to Jeffrey Edward Green's the eyes of the people (Book Symposium on Jeffrey E. Green's The Eyes of the People: Democracy in an Age of Spectatorship). Democratic Theory 2(1): 90-95. https://doi.org/10.3167/dt.2015.020106.

Urbinati, N. (2014) Democracy Disfigured: Opinion, Truth and the People. Cambridge, MA: Harvard University Press.

van Aelst, P., Strömbäck, J., Aalberg, T., Esser, F., de Vreese, C., Matthes, J., et al. (2017) Political communication in a high-choice media environment: A challenge for democracy? Annals of the International Communication Association 41(1): 3-27. https://doi.org/10.1080/23808985.2017. 1288551.

Weber, M. (1921) Parlament und Regierung im neugeordneten Deutschland. Gesammelte Politische Schriften. München: Drei Masken Verlag, pp. 126-260.

Weber, M. (1922) Grundriß der Sozialökonomik, III. Abteilung: Wirtschaft und Gesellschaft. Tübingen: J.C.B. Mohr (Paul Siebeck).

Weber, M. (1978) Economy and Society, ed. G. Roth and C. Wittich. Berkeley: University of California Press.

Weber, M. (1994) The President of the Reich. In P. Lassman and R. Speirs (eds.) Weber: Political Writings. Cambridge: Cambridge University Press, pp. 304-308.

Weber, M. (2019) Economy and Society: A New Translation, ed. and trans. K. Tribe. Cambridge: Harvard University Press. 
West, E.A. and Iyengar, S. (2020) Partisanship as a social identity: Implications for polarization. Political Behavior. https://doi.org/10.1007/s11109-020-09637-y.

Williams, B. (2005) In the Beginning was the Deed: Realism and Moralism in Political Argument, ed. G. Hawthorn. Princeton: Princeton University Press.

Publisher's Note Springer Nature remains neutral with regard to jurisdictional claims in published maps and institutional affiliations. 